\title{
理由に着目した感情表現の構成要素分析
}

\author{
中山 記男 ${ }^{\dagger, \dagger} \cdot$ 神門 典子估市
}

映画や書籍などの作品検索への応用を目的として，作品レビューテキスト中の感情 表現の構成要素を分析した。まずWeb 上の作品レビュー 82 件 1,528 文中の 653 組 の主観表現を人手で分析し，「態度」「主体」「対象」「理由」という４つの構成要素 と, その各々の下位要素を定義した。 653 組の主観表現中，「態度」が感情を表して いる感情は 257 組あった. 次に感情表現の各構成要素の内容や働きを分析し, 構成 要素間の結びつきや,「主体」や「対象」が省略されるパタン, 省略されない特殊な パタンなどを明らかにした。「理由」は，感情が生起した根拠や理由を述べている部 分をさし， 257 組中 66 件 $(25.7 \%)$ に出現した。本稿では, 利用者の作品選択に，よ り具体的な情報を提供しうる可能性がある要素として「理由」に着目し, さらに分 析を進めることとした，次に，異なる文書タイプにおける「理由」の出現のしかた や分析の手がかりを調べるために, Web 上の作品レビュー, オンラインショッピン グ内のブックレビュー, 新聞記事からサンプルを選び,「理由」に着目した追加分析 を行った。最後に，作品検索システム利用者の鑑賞作品選択における「理由」のあ るレビューの重要性を確認するため，3つの映画それぞれ 10 件ずつ計 30 件の作品 レビューを用いて，8名ずつ 2 グループの計 16 名に対し被験者実験とフォーカスグ ループインタビューを行った。この結果, 作品レビューの読み手が第三者の書いた テキストを参考にする際, 「理由」の有無がその内容を理解し, 鑑賞する作品を選択 するのに参考になるかどうかの判断に大きく寄与していることがわかった. 作品検 索では，「理由」の有無や内容をレビューの重要性の順位付け等に応用することなど が考えられる。

キーワード：感情表現, 理由分析, 情報抽出, 情報検索, テキスト分類, 主観情報

\section{Reason-focused Analysis of Emotion Expression-related Components}

\author{
NORIO NAKAYAMA ${ }^{\dagger, \dagger \dagger}$ and NORIKO KANDO ${ }^{\dagger \dagger}, \dagger$
}

\begin{abstract}
As a preparatory study for using emotion in advanced retrieval systems of books and movies, we analyzed expressions of emotion that appeared in film and book reviews, and defined the related components. First, through the manual analysis of $653 \mathrm{sub}-$ jective expressions in 82 book reviews selected randomly from the web, we defined four major components related to expressions of emotion and their subcomponents: "Attitude", "Subject", "Object", and "Reason"; we analyzed the existence of each component and their combinations in the reviews. Second, we found that different writers stated different "Reasons" for the same "Emotion" about the same "Object";
\end{abstract}

†総合研究大学院大学情報学専攻, Department of Informatics The Graduate University for Advanced Studies

†国立情報学研究所, National Institute of Informatics 
that tendency was confirmed in our additional analysis on emotion expressions, in which we focused on "Reasons" using different corpora consisting of film and book reviews and newspaper articles. Finally, we conducted experiments using 16 human subjects in two sessions of focused group interviews. The results showed that "Reasons" associated with emotion expressions appearing in film reviews are important and useful for users to select films relevant for them.

Key Words: Emotion Expression, Sentiment Reason, Information Extraction, Information Retrieval, Text Classification, Subjective Statements

\section{1 はじめに}

インターネット上での商取引やブログの増加により, 特定の商品や出来事についての感情や 評価，意見などの個人の主観を表明したテキストが増加している。この主観の対象が特定の商 品に対するものである時は，商品へのフィードバックとして企業に注目される．主観が特定の ニュースや施策に対するものであれば，国民の反応を知る手がかりとして利用する用途なども 考えられる。国内外で多数の主観に注目した会議が開催されていることからも，関心の高さを うかがい知ることができる（EAAT 2004, Shanahan et al. 2005, 言語処理学会 2005, 言語処理 学会 2006, AAAI2006, EACL2006, ACL2006).

本研究では，このようなテキストに現れた個人の主観の表明の中でも，特に，「うれしい」「か なしい」などの個人の感情を表す感情表現に着目し, その特性を理解するためのモデルを提案 し，書籍や映画などの作品検索に忘用するための方策を考察する．なお感情とは，ある対象に 対する主体の気分や心の動きであり, 感情表現とは, 感情とその主体, 対象などの構成要素をま とめて呼ぶ呼称である。態度とはテキストの中で感情や評価, 意見など主観を表明した部分で ある．感情表現には感情表現事典（中村 1993）に収録されているような感情という態度を表明 している部分だけではなく，それを表明した主体や向けられた対象，その理由や根拠が関連す る構成要素が存在する，我々は書評や映画評などの作品レビューが利用者にとって鑑賞する作 品の選択に参考となるかどうかを判断するためには, 感情表現の中の態度だけでなく他の構成 要素も抽出する必要性があると考える。これは，作品レビューには参考になるもの，ならない ものがあり，それを判断する手がかりとして構成要素が利用されていると仮定したことによる。 さらに構成要素の中でも態度を表明した理由や根拠がその判断に大きく影響していると考えた。

そこでまず感情表現抽出の準備段階として, 感情表現の構成要素をあきらかにするため, Web 上の作品レビューを用いて分析を行い, 感情表現のモデルを定義し, 構成要素の特徵をあきら かにした，次に感情表現の理由や根拠の重要性や働きを調べるため, 追加分析と被験者実験を 行い，作品検索に感情表現を用いるとき，検索結果が利用者にとって参考となる情報となるた めには理由という構成要素が重要な働きをしていることを示した。 


\section{1 作品レビューにおける主観的な情報}

本研究で扱うレビューとは，ある対象について評論したテキストのことである。レビューに は，下記のような多様なドメインが考えられる。

・作品：映画評，ブックレビューや CD，楽曲，演劇などの作品に関するレビュー

・製品：携帯電話や車などの製品についてのレビュー

・サービス：レストランや飛行機, ホテルなどのサービスに関してのレビュー

・組織：会社や団体など, 組織についてのレビュー

これらドメインによって, レビュー中に表明された主観的な情報の用途, 関連する構成要素 と各要素の重要性, 働き, 評価の観点などが異なる，製品においては，使い勝手や好みなどの 主観的な情報も重要であるが，その仕様や機能，価格など製品に関する事実がより重要な観点 となる。同様にサービスではその特徴や利点が, 組織では活動の内容などが重要な観点となる. これら製品やサービス, 組織は利用するためのものであるため, それぞれが持つ機能や特徴, 性 質など主に具体的な事実や数值とそれが好意的なのか否定的なのかという評価がレビューとし て重要視される。しかし映画や書籍のような作品は個人が味わうためのものであり，価格やあ らすじ，登場人物などの事実以上に，それを利用者が読んたり鑑賞したりしてどう感じるかと いった，利用者の抱く感情が重要である.

\section{2 作品検索の問題点}

現在の作品を対象とした検索では，作品のタイトルや登場人物，ジャンルなどを手がかりに して，利用者が自分の希望する作品を検索している。しかし利用者の要求には，「今日は泣け る本が読みたい」「派手な映画を見て元気を出したい」「背筋も凍るような恐怖のホラー映画が 見たい」など，それらを見聞きした結果どのような感情を感じるかといったものもある．実際

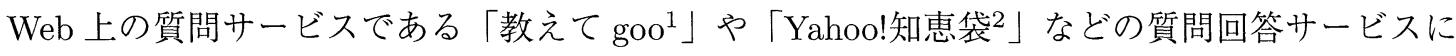
は，「切なくなる本を教えてほしい」「怖い映画を教えてください」などの質問が存在する. 感 情表現を手がかりとして作品を検索できれば，これら要求を満たすことができる。

我々は，単に作品へ向けられた感情表現中の感情という態度を表明した語句のみから作品を 探すのではなく, 感情の主体, 対象, 理由などの感情表現の他の構成要素も利用することが重 要と考える。さらに構成要素の中でも理由，根拠，原因が明記された感情表現が特に利用者に とって参考となり得る重要な情報であると考えた．理由，根拠，原因の記述された感情表現を 検索に利用することで，同じ「幸せな気分になれる本」を探したときでも，「笑える内容だった から幸せだった」のか「ハッピーエンドで終わったから幸せだった」のかなどを区別すること

\footnotetext{
1 教えて goo, http://oshiete.goo.ne.jp/

2 Yahoo! 知恵袋, http://chiebukuro.yahoo.co.jp/
} 
ができる。また，我々は，趣味嗜好が強く反映される作品レビューのようなテキストではそれ を読んだ利用者がテキストに記述された内容を理解し，鑑賞する作品を選択するときに参考に することが可能であることが重要であると考えた。具体的には，感情表現を用いた作品検索に おいて，「理由」が記述されたものに重み付けをし，さらに結果をその作品レビューが含む理由 と共に表示することなどが考えられる.

そこで, 本研究では作品レビューのテキストを対象とし, そこに出現する感情表現を分析し た。なかでも感情表現の理由や根拠に注目して研究を行った。

\section{3 本論文の構成}

本論文の構成は次のとおりである。2 節では, 関連研究を概観し, 本研究の位置づけを明確に する． 3 節では，書籍と映画に関するレビューを人手分析し，感情表現の構成要素を定義した. 4 節では，3 節で定義した構成要素の特徴と働きについて考察をした。 5 節では，構成要素の中 から理由に着目し，その重要性を分析，検討した６節では 5 節での検討内容を被験者実験に よって実証し，7節ではその結果を考察した８節は本論文の結論である.

\section{2 関連研究}

テキストから，「意見」「評価」「感情」など主観表現の態度を抽出，または分類する研究では， 処理対象とする要素が様々である。論文によって要素の名称が異なるが，今節では説明のため 代表的な要素の表記を統一する，対象へ向けられた意見，評価，感情などは「態度」とする．同 様にして態度が向けられた対象は「対象」, 主観を表明した主体は「主体」,「態度」における肯 定的，否定的，中立などの属性を「極性」とする.

\section{1 主観の極性を判定する研究}

テキスト中に表明された主観を扱う研究の中のひとつの大きなグループは，極性を判定する 研究である. Turney（Turney 2002）はWeb 上の映画のレビューテキストから態度を抽出し，そ の極性を検索エンジンを用いて得られた「excellent」または「poor」との共起しやすさから判定 し，さらに抽出された態度の極性の集合から，テキストの極性を判定している．極性を正しく 判定するため, 態度を単語ではなく前後の文脈を追加した句として抽出している. 舘野（舘野 2002）は，企業のサポートセンターによせられた「お客様の声」に含まれる態度に着目し，事前 に行った構文構造解析から木構造を用いて, 否定的な極性を含む文を抽出している. 那須川ら (那須川, 金山 2004）は, デジタルカメラまたは映画について書き込まれているWeb 上の掲示 板から，極性が既に判定されている既知の態度をもとに，新たな態度を極性付きで抽出してい る、極性の判定には，極性が定義されている態度と新たな態度の間に，極性を反転させる「し 
かし」などの表現が出現するかどうかを利用している．立石ら（立石ら 2004）は評判情報検索 に，態度，対象，極性を組み合わせた辞書を用いている．たとえばコンピュータの分野におい て「小さい」が 1,000 表現中 8 回出現し，そのうち 7 回が肯定的なら，コンピュータが対象のと き，「小さい」という態度は肯定的な極性であると判定される．Kim and Hovy (Kim and Hovy 2004）は，態度，主体，対象，極性に着目し，抽出を行っている．主体ごとに極性の方向（肯 定的か，否定的か，中立か）とその強さを計算することで，主体がどのような極性をもってい るか判定している.

\section{2 主観の極性以外の側面も扱う研究}

小林ら（小林ら 2005）は態度，対象，対象の属性を抽出している. 対象の属性とは，対象の 要素のことである，例えば「携帯電話」における対象の属性は「液晶画面」であり，大きな枠 組みである対象と，下位要素である対象の属性を区別している.

Wiebeら（Wiebe et al. 2005）は，手作業でコーパスにタグ付けを行うことにより，態度の構 成要素を定義している。主観的な発言や明示的である率直な態度に関しては, 態度, 主体, 対 象，極性に加え，主観の強さ，表現の強さ，主観に実態があるかどうか（仮定の話か，実際の 話か), の各要素を定義している。表現による主観的な態度については, 態度, 主体, 主観の強 さ，極性を定義している，発話や記述の事実に関しては，発話や記述の部分とその主体，対象 を定義している。

Liu ら（Liu et al. 2003）は，常識知から出来事と感情の組み合わせを学習することで，文を 感情カテゴリに分類している．例えば「自動車事故で恐怖を感じた」という事例から「自動車事 故」は「恐怖」という組み合わせを辞書に登録することにより，「自動車事故にあった」という 文を「恐怖」という感情カテゴリに分類している．田中ら（田中ら 2004）はテキストの情緒を 推定するため，日本語語彙体系をもとに作成した結合価パターンを用いている。この研究で情 緒属性と呼ばれている要素には，「前提条件」「情緒主（主体）」「情緒対象 (対象)」「原因」「情 緒名」がある。「太郎がコンサートのチケットを入手した」という文から情緒主「太郎」は原因 「獲得」から「獲得による喜び」という情緒を導き出している.

大塚（大塚 2004）は，道路計画に対する住民への自由記述アンケートテキストが要求か否か を判定している. 要求の要素として要求動機, 要求内容, 要求意図が定義されている. 要求意 図が明示的に表明されていなくても, 要求動機が出現することでそこに暗黙的な要求意図が存 在すると示されている，例えば「歩道がせまい」という事実を要求動機ととらえることで，「歩 道を広くして欲しい」という暗黙的な要求意困を導き出している。ただしテキストが要求か否 かの判定に関しては，明示的要求のみを対象としている.

これまでの研究において, 我々が「理由」と呼ぶ理由, 原因, 根拠, 動機などは, 態度を導 きだしたり，テキストや文，句などを分類するための手がかりとして扱われてきた．本研究で 
は利用者にとって作品レビューが鑑賞する作品を選択するのに参考になるかどうかを判断する 手がかりとして感情表現の「理由」に着目し，その特性や働きの分析を行った。

\section{3 感情表現のモデル作成}

作品レビュー中の感情表現のモデルを検討するためにグラウンデッドセオリーの「絶えざる比 較法」(Glaser and Strauss 1967) の枠組に従った。データ収集，分析，分析を通じて見えてきた 問題に沿ったデータ収集のサイクルを理論的飽和まで繰り返すことにより，結論を得る（Keith 2005). 分析対象にはWeb 上の書籍および映画の作品レビューを取り上げた。

\section{1 コーパス}

コーパスは，杉田と江口（杉田ら 2001）が2000 年 10 月に収集した作品レビューに関するコ ミュニティに属する 332 の Web サイト上のページである. 本稿では，その中から 6 サイトを無 作為に選択し，さらに各サイトから作品レビューが記述されたファイルを1つずつ選択した「作 品レビューサブコーパス（以下：BSC）」を作成し，実験に用いた．BSC は書籍 64 件と映画 18 件の計 82 件の作品レビューから構成されており，計 1,528 文である. 表 1 に BSC の詳細を示 す。選択した 6 サイトおよびその書き手は重複しない，書き手とは，そのサイトで作品レビュー を書いた人物である，書籍に関する作品レビューは 1 冊の書籍，映画に関する作品レビューは 1 作の映画について書かれたもので，はじめと終わりが読み手に明確なひとまとまりのテキス トを 1 件の作品レビューとした.

表 1 BSC の詳細

\begin{tabular}{|c|c|c|c|c|c|c|}
\hline \multirow{2}{*}{ ファイル ID } & \multirow{2}{*}{ レビュー数 } & \multirow{2}{*}{ 文数 } & \multirow{2}{*}{ 平均文字数 } & \multicolumn{2}{|c|}{ 文字数 } & \multirow{2}{*}{ 文字数 (計)* } \\
\hline & & & & 最大 & 最小 & \\
\hline 274_20 & 17 & 498 & 676 & 1,180 & 429 & 11,493 \\
\hline 103_72 & 13 & 295 & 537 & 824 & 480 & 6,982 \\
\hline 011_29 & 18 & 226 & 318 & 1,153 & 18 & 5,729 \\
\hline 092_9 & 15 & 175 & 228 & 442 & 82 & 3,432 \\
\hline 154_61 & 1 & 119 & 1,691 & \multicolumn{2}{|c|}{-} & 1,691 \\
\hline 156_30 & 18 & 215 & 295 & 630 & 100 & 5,319 \\
\hline 計 & 82 & 1,528 & - & \multicolumn{2}{|c|}{-} & 34,646 \\
\hline
\end{tabular}

*文字数には記号とスペースを含む. 


\section{2 タグ付け}

中山ら (中山ら 2005) は, BSC に対して, 感情だけではなく, 感情, 意見, 評価などの何らか の主観を表明している箇所に着目して, 人手でタグ付けを行い, 主観の表明に関わる一連の構 成要素を含む主観表現のモデルを提案した。BSCに，主観表現は 653 組あり，そのうち，「態 度」が感情と分類された感情表現は 257 組であった。本稿では，この感情表現に着目して，さ らに分析をすすめた。

モデル構築のためのタグ付けの作業は次のとおりである。作業者は著者である。まず，感情 が表明されている箇所に注目し，その「態度」を1つタグ付けした後に，続けてその態度に関 連する他の構成要素を検討した。 タグ付けは作品レビュー単位で行い，1文の中に複数の態度 がある場合や，関連要素が作品レビュー内で文を超えて存在するものも検討の対象とした．同 一箇所に複数の夕グを重複して付与することもできる。作業者である著者の主観により新たな 構成要素が発見されるごとに，その要素をモデルに加え，既に分析済みのコーパスも新たなモ デルでタグ付けをやり直した。この繰り返しによりタグ付けする構成要素を決定しながら BSC 中の全てのテキストにタグ付けを行った。図 1 にタグ付け作業の手順を示す。その結果, 構成 要素として「態度」「主体」「対象」「理由」という 4 つとそれぞれの下位要素を得た。表 2 に感 情表現の構成要素と下位要素の一覧を示す.夕グ付けに際しては開始時と終了時の判断の差が 発生しないよう，終了後にもう1度見直しを行った。見直しでは，各要素を「主体は対象を理 由によって態度と感じた」と同等の文に言い換え，矛盾がないか確認した。

以下，構成要素について説明する。「態度」は主観が表明されていると判断した部分にタグ付 けした。「態度」であるかどうかの判断には, (1)事実報告ではないこと(2)思ったこと, 感じたこ とであることなどを基準とした。表明のタイプについて，態度が明示的に表明されている場合 は「態度記述」，暗黙的に表明されている場合は「ゼロ態度」とした，下位要素について，「態 度」が夕グ付けされた中でも感情だと判断された場合は「感情」, 感情かどうかの判断が難しい

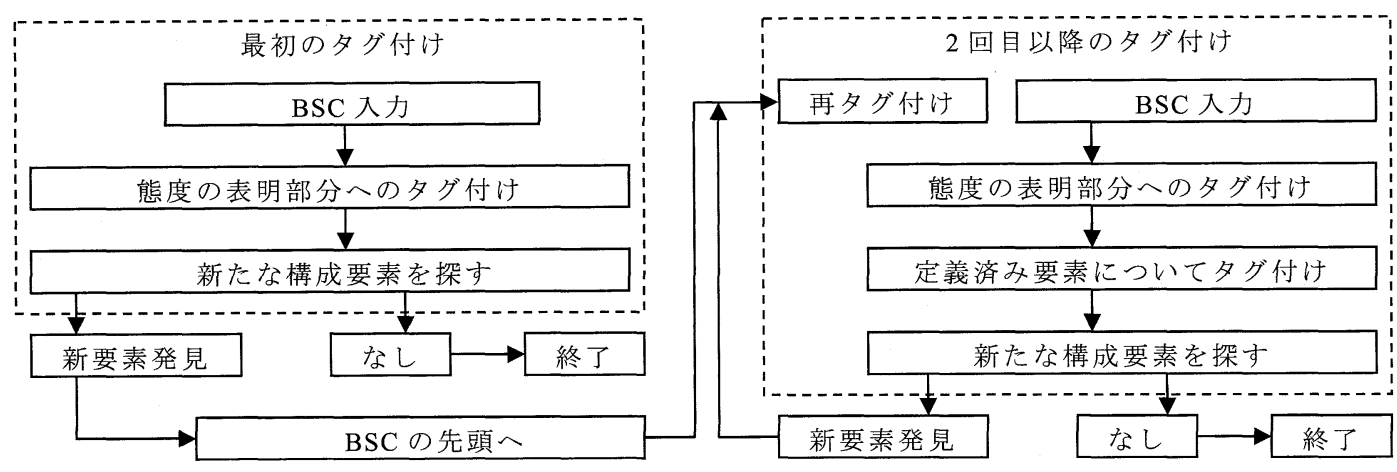

図 1 タグ付け作業の手順 
表 2 感情表現の構成要素と定義

\begin{tabular}{|c|c|c|c|c|}
\hline 上位要素 & 上位要素の定義 & 表明のタイプ & 表明のタイプの説明 & 下位要素 \\
\hline \multirow{3}{*}{ 態度 } & \multirow{3}{*}{ 態度の表明 } & 態度記述 & $\begin{array}{l}\text { 態度が明示的に示され } \\
\text { ている }\end{array}$ & \multirow{3}{*}{ 感情, 保留 } \\
\hline & & ゼロ態度 & $\begin{array}{l}\text { 態度が暗黙的に示され } \\
\text { ている }\end{array}$ & \\
\hline & & 態度なし & 態度が示されていない & \\
\hline \multirow{3}{*}{ 主体 } & \multirow{3}{*}{$\begin{array}{l}\text { 態度を表明した } \\
\text { 人物，モノ }\end{array}$} & 主体記述 & 主体が記述されている & \multirow{3}{*}{ 書き手, 登場人物, 第三者 } \\
\hline & & ゼロ主体 & 主体が省略されている & \\
\hline & & 主体不明 & 主体が不明である & \\
\hline \multirow{3}{*}{ 対象 } & \multirow{3}{*}{$\begin{array}{l}\text { 態度が向けられ } \\
\text { た人物，モノ }\end{array}$} & 対象記述 & 対象が記述されている & \multirow{2}{*}{$\begin{array}{l}\text { 登場人物, 場面, 様子, ストー } \\
\text { リー, 第三者, 発言, 心象, 事 } \\
\text { 実, 行動 }\end{array}$} \\
\hline & & ゼロ対象 & 対象が省略されている & \\
\hline & & 対象不明 & 対象が不明である & \\
\hline \multirow{3}{*}{ 理由 } & \multirow{3}{*}{$\begin{array}{l}\text { 態度を表明した } \\
\text { 原因，理由 }\end{array}$} & $\begin{array}{l}\text { 明確な理由の } \\
\text { 記述 }\end{array}$ & $\begin{array}{l}\text { 明確に理由が記述され } \\
\text { ている }\end{array}$ & 主観理由, 客観理由 \\
\hline & & $\begin{array}{l}\text { 暗黙的な理由 } \\
\text { の記述 }\end{array}$ & $\begin{array}{l}\text { 暗黙的に理由が記述さ } \\
\text { れている }\end{array}$ & 主観理由, 客観理由 \\
\hline & & 理由不明 & 理由が不明である & \\
\hline
\end{tabular}

場合は「保留」とした。これ以降に説明する「態度」以外の上位要素は，夕グ付けされている 「態度」に関連するもののみを検討している。「態度」には「態度なし」という表明のタイプが 存在するが，今回は「態度なし」に該当するものは夕グ付けを行わず分析対象としなかった。

「主体」は「態度」を表明した人またはモノ，「対象」は「態度」が向けられた人またはモノ である。両者の表明のタイプに関して，テキスト中に要素が明示的に記述されている場合はそ れぞれ「主体記述」「対象記述」，明示的に要素が記述されていないが省略されていると判断で きる場合はそれぞれ「ゼロ主体」「ゼロ対象」とした，テキスト中に記述されてなく，かつ該当 するものが無い場合は「不明」とした。それぞれの下位要素として，夕グ付けされたものの属 性である書き手，登場人物，ストーリーなどがある。

「理由」は「態度」を表明した原因, 理由, 根拠となる部分である。「理由」の表明のタイプ に関しては「記述されていない」もの, 語尾が（から｜ため|ので|よって）または（すれば| してくれば|なら）という表現であるかこの表現に言い換えることのできる「明確に理由が記 述されている」もの，語尾を（を理由として|を原因として）と大きく言い換えることで「理 由」であると判断できる「暗黙的に理由が記述されている」ものに分類した。「理由」の下位要 素は「主体の主観的な判断によるもの」を「主観理由」，「事実によるもの」を「客観理由」と した。「理由」に関しては，5節で詳しく考察をした。 
表 3 タグ付けの例

[作品レビューA]

アフリカのある小さな村で、憾染するとほとんど死に至るという\}r1、恐ろしい\}a1 伝染病\}o1 が発 生した。そして、このウイルスがひょんなことからアメリカにもちこまれる。米国陸軍伝性病医学研究 所のサムは、この伝染病を防ぐべく動くが、そのアイルスに効く血清を陸軍が持っていることを知り、 この騒動の襄にある事実を探ることになる。

○\{タイムリーな話題だけに $\mathrm{r} 2 \quad\{\cdot \cdot \cdot \cdot\} \mathrm{a} 2$

亿の映画公開の頃、エボラ出血熱の話題が世間を賑わせていただけに\}r3、映画を観ていても \{怖い ものがありました $\mathrm{a} 3$ 。\{感染した猿が少女に近寄っていく\}r4ところ\} 04 なんかは、\{もうドキド キ! \}a 4 そして、観る前はただのパニック映画かと\}a5 思っていたのですが、\{ストーリーは筋書きの 見えない展開を見せ $\mathrm{r} 6$ 、价なり楽しめました\}a6。

[作品レビューB]

ストーリーについては、\{\{タイトルである「慟哭\}r７」\}o7という \{胸をえぐるほどの悲しみの 咆哮\}a7を思わせるのに比べ、倳件を\{たんたん\} a 9 と追う\}o9\}r8 \{文体の印象\}o8が $\{$ かえっ て心に残ります\}a8。しかし、なぜか 私\}s10は\{主人公の行動\}o10, o11を 亿ひどい、とは思えなかっ た\}a10，r11のです。むしろ、侗情さえしてしまいます\}a11。これは前の「天使の屍」などを読んだ 時もそう思ったのですが、極端な言い方をすれば、傢族や親子の絆\} 012 というのは \{人の心を暖か くさせるのと同時に何かを狂わせてしまうほどの力も持っているのではと思わずにいられません\}a12。 \{\{小骨が体の奥に残ったような\}a13、楛々しい思いを残した\}a14 読後感\}o13, o14\}r15 r゙ した。しかし、その 䇚力\}o15にも 感服\}a15。

*記号は \{夕グ付け部位 $\}$ 要素の種類 番号である. 例：態度 $\}$ a 住体 $\mathrm{s}$ 対象\}o $\{$ 理由\}r

タグ付けされた作品レビューの例を表 3 に，そこから抽出した要素の一覧を表 4 に示す. 同 一箇所に複数の夕グが付与される例として, 表 3 の作品レビューAでは, ある態度について同 じ部分が「対象」「理由」になっている例（o4，r4）を，作品レビューBではある態度に関して は「理由」とタグ付けされている部分に別の態度についての構成要素がある例（r8, a9 な゙）を 含んでいる。

\section{4 タグ付けの結果}

4.1 節では感情表現に関する夕グ付けの結果を報告し，4.2 節では，「理由」の特性や下位要素 を検証する分析をした. 4.3 節では複数分析者間の一致度調査の結果を報告する. 4.4 節では感 情表現の「理由」の働きについて考察を行った。これら分析により, 感情表現の構成要素の特 徵やパタンをあきらかにし，また「理由」の重要性を検討した。 
表 4 表 3 で夕グ付けられたタグの詳細

\begin{tabular}{|c|c|c|c|c|c|c|c|c|}
\hline No. & 態度\} a & 下位要素 & 住体\}s & 下位要素 & 対象\}。 & 下位要素 & 理由\} r & 下位要素 \\
\hline 1 & 態度記述 & 感情 & ゼロ主体 & 書き手 & 対象記述 & 登場するモノ & 明確 & 客観理由 \\
\hline 2 & ゼロ態度 & 保留 & ゼロ主体 & 書き手 & ゼロ対象 & 作品 & 明確 & 主観理由 \\
\hline 3 & 態度記述 & 感情 & ゼロ主体 & 書き手 & ゼロ対象 & 作品 & 明確 & 客観理由 \\
\hline 4 & 態度記述 & 感情 & ゼロ主体 & 書き手 & 対象記述 & 場面 & 暗黑的 & 客観理由 \\
\hline 5 & 態度記述 & 保留 & ゼロ主体 & 書き手 & ゼロ対象 & 作品 & 理由不明 & \\
\hline 6 & 態度記述 & 感情 & ゼロ主体 & 書き手 & ゼロ対象 & 作品 & 明確 & 主観理由 \\
\hline 7 & 態度記述 & 感情 & ゼロ主体 & 書き手 & 対象記述 & 作品のタイトル & 暗黙的 & 客観理由 \\
\hline 8 & 態度記述 & 感情 & ゼロ主体 & 書き手 & 対象記述 & 書き方 & 明確 & 主観理由 \\
\hline 9 & 態度記述 & 感情 & ゼロ主体 & 書き手 & 対象記述 & ストーリー & 理由不明 & \\
\hline 10 & 態度記述 & 感情 & 主体記述 & 書き手 & 対象記述 & 登場人物 & 理由不明 & \\
\hline 11 & 態度記述 & 感情 & 主体記述 & 書き手 & 対象記述 & 登場人物 & 暗黙的 & 主観理由 \\
\hline 12 & 態度記述 & 保留 & ゼロ主体 & 書き手 & 対象記述 & 事象 & 理由不明 & \\
\hline 13 & 態度記述 & 感情 & ゼロ主体 & 書き手 & 対象記述 & 心象 & 理由不明 & \\
\hline 14 & 態度記述 & 感情 & ゼロ主体 & 書き手 & 対象記述 & 心象 & 理由不明 & \\
\hline 15 & 態度記述 & 感情 & ゼロ主体 & 書き手 & 対象記述 & 書き方 & 暗默的 & 主観理由 \\
\hline
\end{tabular}

\section{1 感情表現の分析}

感情表現 257 組についての分析を行い, 感情表現の構成要素の特徵や出現パタンを調べた. タグ付けされた上位要素の組み合わせ件数の一覧を表 5 に示す.

\subsection{1 構成要素}

表 5 に示すように，もっとも多くタグ付けされた上位要素の組み合わせは，

\section{[態度あり $]+[$ 主体あり $]+[$ 対象あり $]+$ －理由不明 $]$}

であり，257 組の中で 170 組あった。「主体」は全ての 257 件あり，うち記述あり 22 件，ゼ ロ主体 148 件であった。「対象」は 236 件で, うち記述あり 181 件, ゼロ対象 55 件だった.「理

表 5 BSC に出現した感情表現に関する上位要素の組み合わせ

\begin{tabular}{ccccccc}
\hline 上位パタン ID & 態度 (感情) & 主体 & 対象 & 理由 & 組数 & 割合 \\
\hline 1 & $\bigcirc$ & $\bigcirc$ & & & 21 & .082 \\
2 & $\bigcirc$ & $\bigcirc$ & $\bigcirc$ & & 170 & .661 \\
3 & $\bigcirc$ & $\bigcirc$ & $\bigcirc$ & $\bigcirc$ & 66 & .257 \\
\hline 計 & 257 & 257 & 236 & 66 & 257 \\
\hline \multicolumn{7}{c}{ ○は記述またはゼロの場合. }
\end{tabular}


由」は 66 件で, うち明確 54 件, 暗黙 12 件だった。「対象」は作品レビューの対象書籍または 映画であるものが 50 件で最も多く，他で多かったものとしては，事実が 40 件，登場人物が 38 件，場面が 28 件だった。

\subsection{2 構成要素の特徵と考察}

「対象」 236 件のうち，45 件は記述が省略されている「ゼロ対象」であった．また，「書き手」 以外の「主体」が夕グ付けされた例は全部で 23 件あった. 主観表現全体で 24 件あったうち 23 件が「感情」で見られ，書き手以外の「主体」が夕グ付けされている部分では，ほぼ感情が表 明されている。感情表現の処理において，構成要素のうち「主体」が省略されているかどうか は重要な要素であると考える。書き手自身が「主体」であるとき「主体」の表記が省略される ことの多い日本語において，あえて「主体」が記述されるときは，主体が自らの意見について 自信がない，もしくは自らの意見が特殊であると自認している特別な場合だった.

また，下位要素が「書き手」以外の「主体」が夕グ付けされた例は全部で 24 件あった. うち 22 件は登場人物の感情を記述したものであり，あらすじの説明中に出現したものが多かった。 作品レビューの書き手が表明した「感情」と，作品内で登場人物が表明した「感情」では意味 が異なるため，区別しなくてはならない。これはレビューの書き手による「感情」は主観的な 情報であるのに対し，登場人物の「感情」は作品の一部で客観的な情報だからである．同様に して，作品に向けられた「感情」と作品以外に向けられた「感情」も区別する必要がある.そ のため作品レビューを処理する際には, タイトルと記事, 作品レビューの地の部分とあらすじ の記述箇所の切り分けなど，テキスト全体の構造に着目した処理も必要である.

また, 中山ら (2005) で行った, 感情, 意見, 評価などの多様な主観の表明に関わる表現の分 析と比較しても, とくに, 感情表現のみの顕著な傾向は見られなかった。

\section{2 「理由」について}

\subsection{1 明確な「理由」と暗黙的な「理由」}

感情表現の「理由」は 66 件あった。「理由」は表明のタイプとして明確なものと暗黙的なも のに分類できた。それぞれの理由の表明のタイプは，タグが付与された部分の語尾が以下に示 す 3 つのパタンのいずれかであるか，言い換えることができるものを指す.

(から|ため|ので|よって) +「態度」明確(1)

(すれば|してくれば|なら）＋「態度」明確(2)

（を理由として|を原因として）＋「態度」暗黙的

明確な理由(1)に当てはまるものは 47 件あった. 明確な理由(2)にてはまるものは 4 件あっ た. 暗黙的な理由は 15 件あり，うち 6 件は「対象」と「理由」の夕グ付与が重なっていた. 暗黙的な理由をさらに分析すると下記のカテゴリを見出すことができた. 
I. 作品レビューのドメインに依存した対象（場面・ストーリー・登場人物）の説明が理由になっ ているもののうち，直接的な因果関係が成立しないため，「〜ので」「〜から」などに言い換え られないもの
Ia. 個々の場面 (6 件)
Ib. 全体のストーリー（2 件 $)$
Ic. 登場人物 (3 件)
Id. 視線移動（1 件）

II. 分析者の体験・世界知識が理由となっているもののうち，「〜ので」「〜から」など直接的な 因果関係に言い換えられないもの $(3$ 件 $)$

このうち，Iのような具体的な場面，ストーリー等に関連する理由は，「〜ので」「〜から」な どには言い換えられないが，「〜を理由として」「〜を原因として」には言い換えることができ， また，後述する複数分析者間の一致度調査でも一致して判定された割合が高かった，それに対 し，II は，個々の判定者の個人的な体験や世界知識に関連するものであり，他者との共有や理 解は難しい場合もある.

\subsection{2 主観的な「理由」と事実による「理由」}

「理由」には，下位要素として主観的なものと事実による客観的なものがあった。木戸（木 戸，佐久間 1989）によれば，文の機能として「根拠：判断のよりどころとなった事実を提示す る機能」，「理由：判断のよりどころとなった意見を提示する機能」と定義されている．本研究 が「理由」の下位要素として定義した「主観理由」は後者の「判断のよりどころとなった意見 を提示する機能」に，「客観理由」は前者の「判断のよりどころとなった事実を述べる機能」に あたる。

「理由」の 66 件中, 「主観理由」は 33 件,「客観理由」は 30 件, どちらとも判断つかず保留 したものが 3 件あった。「主観理由」には書き手の考えが，「客観理由」には書籍の内容や書き 手の状況が多かった. 表 6 に件数の一覧を, 表 7 に下位要素の例を示す.

表 6 「理由」の下位要素の件数

\begin{tabular}{|c|c|c|c|c|c|}
\hline & \multicolumn{2}{|c|}{ 明 確 } & \multirow{2}{*}{ 暗 } & \multirow{2}{*}{ 黑 } & \multirow{2}{*}{ 計 } \\
\hline & (1) & (2) & & & \\
\hline 主観理由 & 22 & 2 & & 9 & 33 \\
\hline 客観理由 & 23 & 1 & & 6 & 30 \\
\hline 保 留 & 2 & 1 & & 0 & 3 \\
\hline 計 & 47 & 4 & & 15 & 66 \\
\hline
\end{tabular}


表 7 「理由」の下位要素の例

\begin{tabular}{|c|c|c|c|}
\hline 下位要素 & 表明のタイプ & 例 & 態 度 \\
\hline \multirow{5}{*}{ 主観理由 } & 明確(1) & 本格ものだと意識したため & とまどいました \\
\hline & 明確(1) & 現実とも虚構とも境目のつかない & 恐怖 \\
\hline & 明確(2) & 飼っているのがく竜〉ならば & 新鮮な出来事 \\
\hline & 暗黙 & 加速する視線移動 & 耐えられない \\
\hline & 暗黙 & 話の中の世界なのか錯綜した場面 & すごく怖い \\
\hline \multirow{5}{*}{ 客観理由 } & 明確(1) & 警察内部の批判を受けて & 懊恼する \\
\hline & 明確(1) & ろくに挨拶もしなかった & 怒っていた \\
\hline & 明確(2) & ハンドブック 1 と分けて書いちゃ & 意味が無いでしょう \\
\hline & 暗黙 & 容赦なく降りかかる難題 & ハラハラし通し \\
\hline & 暗黙 & 感染したサルが少女に近寄っていくところ & もうドキドキ \\
\hline
\end{tabular}

\section{3 分析者間でのタグ付与一致度}

タグの信頼性を調査するため，3 名の分析者による夕グ付けの一致度調査を行った．分析者 1 は 20 代女性，分析者 2 は 20 代男性，分析者 3 は BSC 全体の夕グ付けを行った著者である。い ずれの分析者も大学院生である. 分析対象として BSC82 件全体（1,528 文）の中から 10 件（150 文）を無作為に選んだ。タグ付けは 3.2 節に示した構成要素に関して行った。感情表現の夕グ 付与のみの一致度調査では, 比較する件数が少なかったため, 感情のみではなく, なんらかの 主観を表明した箇所に関して，関連する構成要素を夕グ付与し，その一致度を調査した。 4.3 .2 節では，分析者間で夕グ付与に摇れが現れることが予想される「態度」と「理由」に関して考 察する。

\subsection{1 分析者間での態度タグ付与}

表 8 に各分析者が「態度」タグを付与した数と, その中でも 3 名の分析者が同じ部分に「態 度」夕グを付与した数を示す。分析者 1 , 分析者 2 , 分析者 3 は, それぞれ 70 件, 144 件, 98 件 の「態度」をタグ付与し，そのうち 3 名が同じ部分にタグ付与したものは 52 件あった。

分析者間でのタグ付与の一致度は，2つの調査で評価した. 表 9 に各分析者間の「態度」夕グ 付与一致率 3 とコーエンの $\kappa$ 係数 (Cohen 1960) によりもとめた各分析者間での「態度」夕グ付 与の一致度 4 を示す. 分析者 1 と 3 の態度夕グ付与には高い一致が見られたが，分析者 2 は，分 析者 1 および 3 との一致は中程度であった。

\footnotetext{
3 一致率は，比較する分析者同士での同じ部分にタグを付与した割合の平均で求めた.

4 夕グ付与される可能性のある部分 281 䇢所を仮定し, 共通で夕グ付与しなかった部分も一致として計算した. 281 箇所は，1 行あたりに含まれる態度の数の平均值を求め，それを全行数にかけあわせて計算した。
} 
表 8 各分析者が「態度」をタグ付与した数

\begin{tabular}{ccccc}
\hline & 分析者 1 & 分析者 2 & 分析者 3 & 3 名が同じ部分に付与 \\
\hline Text1 & 11 & 15 & 14 & 9 \\
Text2 & 11 & 26 & 13 & 8 \\
Text3 & 11 & 17 & 10 & 7 \\
Text4 & 4 & 6 & 7 & 3 \\
Text5 & 5 & 11 & 7 & 4 \\
Text6 & 5 & 16 & 9 & 5 \\
Text7 & 7 & 18 & 15 & 6 \\
Text8 & 6 & 15 & 13 & 5 \\
Text9 & 2 & 1 & 3 & 1 \\
Text10 & 8 & 19 & 7 & 4 \\
\hline 計 & 70 & 144 & 98 & 52 \\
\hline
\end{tabular}

表 9 各分析者間での「態度」タグ付与一致率と $\kappa$ 係数

\begin{tabular}{ccc}
\hline 比較する分析者 & 一致率 & $\kappa$ 係数* \\
\hline 分析者 1 と 2 & .637 & .325 \\
分析者 1 と 3 & .808 & .679 \\
分析者 2 と 3 & .583 & .298 \\
\hline *(Landis et al. 1977) の評価基準によれば, $0.41-0.6$ の值は中程
\end{tabular}

度 (moderate) の一致であり，0.6-0.8の值は十分 (substantial) な一致である。

\subsection{2 分析者間での理由タグ付与一致度}

前節にて 2 名以上が同じ部分に「態度」が付与された 87 件それぞれの「理由」について，そ の一致度を調査した。「理由」の夕グ付け部分が同じかどうかは著者が判定した。複数者が「理 由なし」とした場合も一致していると数えた。 87 件中で「態度」を付与した 2 名以上が同じ部 分に「理由」を付与したものでは $86.2 \%$ の 75 件あった.中でも 2 名両者または 3 名全員が同じ 部分に「理由」を付与したものは $66.7 \%$ の 58 件あった。まったく一致しないものは $13.8 \%$ の 12 件あった。

分析者間での一致度を表 10 に示す。被験者間での「理由」付与について，7割以上の一致が 確認された．感情表現の夕グ付けは個々の判定者の主観による摇れを含むやや難しいタスクで あるが, 共通して認識される要素も少なくなく, 本稿のタグ付けも一定の範囲で信頼性が確保 されたと考える。 
表 10 分析者間での「理由」付与の一致率

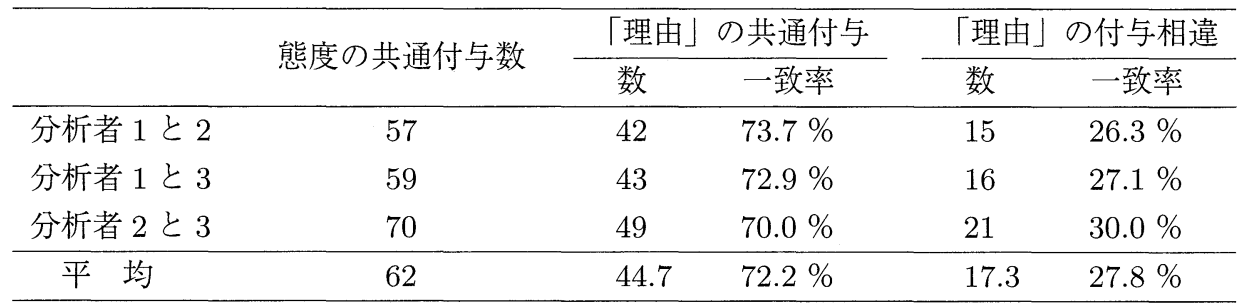

\section{4 「理由」についての考察}

態度のように主観的な情報では「いいですね」と思った「理由」は様々である，我々は，この 理由こそが利用者の知りたい情報となるのではないかと考える。これは同一態度であってもそ の理由が異なれば，まったく違った情報になる場合があるからである．例えばストーリー重視 で作品を探す利用者にとって，最も有用な情報となるのは，ストーリーの良さを理由にした「こ の作品はいいですね」などの肯定的表現である。このことから態度がどんな理由で表明された かが，作品レビューの感情表現をもとに作品を検索する際には重要となり，かつ利用者がその レビューを信頼し，参考にできるかどうかに関連すると仮説を立てた。そこで我々は，「理由」 の働きを確認するため，次節以降で追加分析を行った.

\section{5 「理由」の特性の分析}

5.1節では，レビューに対して評価がつけられている Amazon.co.jp にて，参考になるレビュー と参考にならないレビューとで「理由」の出現に違いがあるのかを示した． 5.2 節では「理由」 が同じ作品に同じ感情を感じた場合であっても様々であることを調べ，「理由」を提示すること の必要性を示した。 5.3 節では異なるジャンルである新聞記事にて，「理由」がどのように存在 するのかを調査し，そこから「理由」の重要性を分析した。これらの分析により，作品検索に おいて利用される作品レビューが参考になるかどうかという面での「理由」の重要性を示した.

\section{1 「理由」は利用者に求められているか}

Amazon.co.jp ${ }^{5}$ のスタマーレビューには，そのレビューが参考になったかどうかの投票シス テムがある。これを用いて，感情表現の「理由」が明記してあるレビューとそうでないレビュー では，参考になる度合いが違うかどうかを調査した。 2004 年書籍べストセラー上位 5 冊の書籍 について，書かれてから 1 ケ月以上経過しているレビューから，それぞれ最も参考になってい

\footnotetext{
5 Amazon.co.jp, http://www.amazon.co.jp/
} 
るレビュー 10 件, 最も参考になっていないレビュー 10 件, 計 100 件のレビューに感情表現の タグ付けを行い，その内容を比べた。 タグ付けは著者が行った。それぞれのレビューに含まれ た感情表現のうち，何件が「理由」を持つかを調べた結果を表 11 に示す.

参考になったレビューには，参考にならないものに比べ，「態度」と「理由」ともに多く含まれ

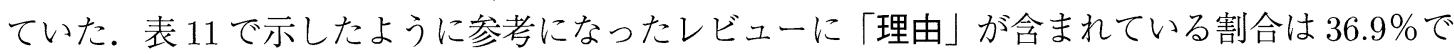
ある。参考にならないレビューで「理由」が含まれる割合は $24.5 \%$ であり，両者にはカイ二乗 検定により優位水準 5\%で優位差があった。このことからも，参考になったレビューには理由が 含まれる割合が高いといえる，参考になったレビューには，好意的なもの，批判的なものも含 め，なぜそう思ったのか，つまり「理由」をわかりやすく書いてあるものが多かった．また「理 由」以外にも簡単なあらすじや，どんな人に最適かが書かれているものが多かった。 それに対 して参考にならないレビューでは, 単に「面白い」や「つまらない」と書いてあるものや, 参考 になったものに比べ理由が不明確であるもの, さらに書籍とは関係のない内容などが多く, 利 用者にとって有効な情報になっていないと考える.

この結果から，参考になるレビューには参考にならないレビューよりも「理由」が記述され ている「態度」が多く，参考になるものとならないものを区別するひとつの手がかりになって いるのではないかと考えた。

\section{2 「理由」には多様性があるか}

同じ「対象」, 同じ「態度」で「主体」が異なる場合において，「理由」に多様性があるかを 確認するため, 新たなテキストを用いて詳しく分析した。これはある作品に対して同様に「面 白かった」という結論を示している作品レビューにも参考にできるものとできないものがある のは，「理由」の多様性に一因があるのではないかと考えたためである。

表 11 参考になるレビューとならないレビュー

\begin{tabular}{|c|c|c|c|c|c|c|c|c|c|c|}
\hline & \multicolumn{5}{|c|}{$\begin{array}{l}\text { 参考になったレビューの中 } \\
\text { に出現した感情表現 }\end{array}$} & \multicolumn{5}{|c|}{$\begin{array}{l}\text { 参考にならないレビューの中 } \\
\text { に出現した感情表現 }\end{array}$} \\
\hline & \multicolumn{2}{|c|}{ 理由あり } & \multicolumn{2}{|c|}{ 理由なし } & \multirow{2}{*}{$\begin{array}{r}\text { 総数 } \\
79\end{array}$} & \multicolumn{2}{|c|}{ 理由あり } & \multicolumn{2}{|c|}{ 理由なし } & \multirow{2}{*}{$\begin{array}{r}\text { 総数 } \\
32\end{array}$} \\
\hline 書籍 $\mathrm{H}^{*}$ & 32 & $40.5 \%$ & 47 & $59.5 \%$ & & 7 & $21.9 \%$ & 25 & $78.1 \%$ & \\
\hline 書籍 B & 29 & $29.6 \%$ & 69 & $70.4 \%$ & 98 & 8 & $30.8 \%$ & 18 & $69.2 \%$ & 26 \\
\hline 書籍 G & 13 & $27.1 \%$ & 25 & $72.9 \%$ & 48 & 2 & $7.1 \%$ & 26 & $92.9 \%$ & 28 \\
\hline 書籍 J & 19 & $38.8 \%$ & 30 & $61.2 \%$ & 49 & 13 & $36.1 \%$ & 23 & $63.9 \%$ & 36 \\
\hline 書籍 P & 16 & $40.0 \%$ & 24 & $60.0 \%$ & 40 & 9 & $24.3 \%$ & 28 & $75.7 \%$ & 37 \\
\hline 全体 & 109 & $36.9 \%$ & 195 & $63.1 \%$ & 304 & 39 & $24.5 \%$ & 120 & $75.5 \%$ & 159 \\
\hline
\end{tabular}


BSC ではこの条件にあてはまる例が確認できなかったため, goo ブログ検索6を用いて検索し た，映画「交渉人真下正義」および「チャーリーとチョコレート工場」に関する作品レビューを 新たなコーパスとして利用した。同じ「対象」に同じ「態度」を表すテキストとして，「楽しめ た」という感情表現の記述があり，なおかつ「理由」の記述があるもので，「交渉人真下正義」 および「チャーリーとチョコレート工場」に関する作品レビューをそれぞれ 10 件ずつ，計 20 件選択した。これを映画レビューコーパスと呼ぶ。映画レビューコーパスへの構成要素の夕グ 付けは著者が行った．映画レビューコーパスのテキスト中の「楽しめた」という感情表現に対 応する「理由」を表 12 に示す．同じ作品を「対象」とし，同じ「態度」を感じたとしても，人 によりその「理由」が異っている。これは同じ作品に対し「楽しめた」という感情を持ったと しても，人によってそれを感じる部分（場面）が違うためである.

実際に「理由」とされた内容を見ていくと，「交渉人真下正義」ではテンポやノリ，ドキドキ

表 12 「楽しめた」理由を抜き出した結果

\begin{tabular}{|c|c|}
\hline 作 品 & 「理 由」 \\
\hline \multirow{10}{*}{ 交涉人真下正義 } & 警察署の三人組が次回予告編分で出演していて \\
\hline & 素直にバラエティ作品を作ろうって感じがして \\
\hline & とてもドキドキハラハラして \\
\hline & 娛楽作品として \\
\hline & 軽〜いノリで \\
\hline & 日本映画の割には、迫力ある映像が次々とテンポよく出てくる \\
\hline & 結構ドキドキ感があって \\
\hline & 脇キャラたちがかなり個性的で \\
\hline & テンポがよくて \\
\hline & $\begin{array}{l}\text { すごくストーリーも面白かったし、「踊る〜」ならではの、ネタもいっぱい散りば } \\
\text { められていて }\end{array}$ \\
\hline \multirow{10}{*}{$\begin{array}{l}\text { チャーリーと } \\
\text { チョコレート工場 }\end{array}$} & 思ったよりも毒のある映像で \\
\hline & 独特の世界に引き込まれてしまって、退屈することもなく \\
\hline & テイム・バートン好きだし、ジョニー・デップ大好きだし、 \\
\hline & 映像も細かいところまで完璧に造りこまれているので \\
\hline & ウンパ・ルンパの曲や踊りや工場の中がこうなったのかあ、と \\
\hline & 原作を読んでいないのですが、映画だけで \\
\hline & なんか夢があって。それでいて現代とも通じるリアルな部分もあって。 \\
\hline & ジョニーディップの個性的な表現があり \\
\hline & こういう社会を皮肉ってる映画は嫌いじゃないので \\
\hline & 普段からもっと洋画見てたら \\
\hline
\end{tabular}

${ }^{6}$ goo ブログ検索, http://blog.goo.ne.jp/ 
感が挙げられており，この映画の特徴の中でも楽しめた部分を指している。「チャーリーとチョ コレート工場」では世界観や役者の演技などが挙げられており，前者の「交渉人真下正義」と は異なる「楽しめた」理由が示されている。このような「理由」の多様性が参考にできるもの とそうでない作品レビューを生み，結果として「理由」が利用者にとって必要とされていると 考える.

\section{3 異なるジャンルにおける「理由」の特徵}

作品レビューにおける「理由」の特徵を明確にするために，異なる文書ジャンルでの「理由」 について比較分析を行った，異なる文書ジャンルとして新聞記事（社説を含む）をとりあげた． この分析において作品レビューはBSC を, 新聞記事は，一例として Googleニュース日本版で゙ 上位にランキングされていた 30 件を利用した。これを新聞記事コーパスと呼ぶ．新聞記事コー パスにおける構成要素のタグ付けは筆者が行った．新聞記事コーパスのテキストには感情表現 がほとんど含まれないため，ここではBSCにおける主観表現の「理由」と，新聞記事コーパス に打ける主観表現の「理由」を比較分析した。

$\mathrm{BSC}$ 全体で「理由」が 653 件中 151 件， $23.1 \%$ 出現していたのに対し，新聞記事コーパスでは $73.2 \%$ で出現していた。両者にはX二乗検定にて優位水準 $1 \%$ で有意差が見られ, 新聞記事コー パスのほうが「理由」が出現する確率が高い。これは新聞記事では読み手に納得，理解させる ことや，記事の信頼性が問われるため，「理由」を記述することで読み手に訴えかけているので はないかと考えた。また BSC には客観理由が $44.4 \%$, 主観理由が $49.0 \%$ と同じ程度で出現して いたのに対し，新聞記事コーパスでは主観理由が $44.3 \%$ ，客観理由が $55.6 \%$ あった。これに ついては，同じくX二乗検定にて優位水準 $5 \%$ までは有意差があると言えず，有意水準 $10 \%$ で はじめて有意差があるといえた。ただし，この中で 10 件ある郵政民営化問題と解散総選挙問 題だけを取り上げてみると, 客観理由は $75.0 \%$ にをり, 記事の内容によって書き手の主観が 「理由」になりやすいニュースと，そうでないニュースがある，BSCにおける「理由」におい て, 客観理由ではストーリーや登場人物の行動などの作品の内容を「理由」として書き手の感 情が表明されたケースが多かった，主観理由では，「物語の力強さ」「まるで自分も登場人物の 一人になったかのよう」など，書籍に書かれている内容や映画に映っている内容以外に対する 書き手の考え, 状況, 様子を「理由」として, 書き手の感情を表明していた，BSCに比べ新聞 記事コーパスは小規模であるが, 異なるジャンルにおける「理由」の特徵の違いが示唆された。

\footnotetext{
7 Google ニュース日本版, http://news.google.co.jp/
} 


\section{6 被験者実験}

\section{1 「理由」の働きと重要性に関する被験者実験}

感情表現の「理由」が作品レビューを読む利用者にとってどのような働きをしているのかを 分析するために，被験者実験を行った，被験者は，都内の大学生 16 名であり，8名ずつの 2 グ ループに分けて行った. グループX は文系女子大の学生 8 名, グループ Y は理工系の男子学生 8 名である．被験者に映画に関する作品レビューを読んでもらい，見る映画を選択する上で参 考になる部分に下線を付与してもらった。実験手順は次の通りである。

I. 事前アンケート

II. 被験者による下線付与

III. フォーカスグループインタビュー

被験者実験により，5節で示した「理由」の重要性に関して，実際に作品レビューがどのよう に読まれているかという面から分析する。

\subsection{1 事前アンケート}

被験者のインターネット利用時間などを調ベた。主要な回答結果を表 13 に示す.

\subsection{2 被験者による下線付与}

分析対象は, 表 14 に示す 3 つの映画の各々について, ブログに書かれた作品レビューを 10 件 ずつ, 計 30 件である. 作品レビューはgoo ブログ検索 [11] を用いて各映画のタイトルで検索し た結果の上位から, 主に映画について書かれているものを 10 件選択した. 30 件の作品レビュー の書き手は全て異なる．各映画には M1〜 M3，各作品レビューには R1〜R30という ID を付与 した. R1〜R10は M1の，R11〜R20 は M2 の，R21〜R30は M3の作品レビューである．この 実験に用いた映画の作品レビューの集合を実験用レビューと呼ぶ. 実験用レビューを分析する ためのタグ付けは筆者が行った。実験用レビューの詳細を表 15 に示す.

16 名の被験者に提示した実験用レビューは同じものであるが，提示する順番による結果への 影響を考慮し，提示した順は被験者それぞれで異なっている。調査はグループごとに 8 名ずつ まとめて行い, グループXとグループYの調査日時, 調査場所は異なっている．各被験者は, 3 つの映画についての情報を探しており，その情報をもとに映画を見るかどうか決めようとし ている状況を想定するよう求めた.

実験には実験用レビューを 1 件ずつ紙に印刷したものを用いた。被験者には，1件の作品レ ビューの中で被験者が参考にできると感じた部分があればそこに下線を，さらにその作品レ ビューの中で特に参考になった部分があれば下線と丸印を付与するよう求めた。被験者が提示 された順に作品レビューを読み，下線を付与する。作業時間に制限はないが，作業は 1 つの作 
表 13 事前アンケートの回答結果

\begin{tabular}{|c|c|c|c|c|c|c|}
\hline \multirow{2}{*}{ ID } & \multirow{2}{*}{ PC 利用歴（年） } & \multirow{2}{*}{ ネット利用歴（年） } & \multicolumn{2}{|c|}{ ネット利用時間（週） } & \multirow{2}{*}{$* 1$} & \multirow{2}{*}{$*_{2}$} \\
\hline & & & 学業 & 趣味 & & \\
\hline $\mathrm{X} 1$ & 10 & 10 & 6 & 6 & 0 & 0 \\
\hline $\mathrm{X} 2$ & 7 & 7 & 4 & 30 & $\times$ & O \\
\hline $\mathrm{X} 3$ & 7 & 4 & 3 & 7 & 0 & $x$ \\
\hline $\mathrm{X} 4$ & 4 & 4 & 7 & 5 & 0 & $x$ \\
\hline $\mathrm{X} 5$ & 4 & 4 & 7 & 5 & $\times$ & $x$ \\
\hline $\mathrm{X} 6$ & 3 & 3 & 1 & 5 & $\bigcirc$ & $x$ \\
\hline $\mathrm{X} 7$ & 7 & 7 & 0 & 14 & 0 & 0 \\
\hline $\mathrm{X} 8$ & 11 & 8 & 1 & 1 & 0 & 0 \\
\hline $\mathrm{X}$ の平均 & 6.63 & 5.88 & 4.0 & 9.1 & & \\
\hline $\mathrm{Y} 1$ & 10 & 6 & 15 & 30 & $O$ & O \\
\hline $\mathrm{Y} 2$ & 4.5 & 4.5 & 7 & 7 & $x$ & $x$ \\
\hline Y3 & 10 & 9 & 7 & 4 & 0 & 0 \\
\hline $\mathrm{Y} 4$ & 9 & 7 & 7 & 35 & $\times$ & $\bigcirc$ \\
\hline Y5 & 4 & 4 & 16 & 12 & $x$ & $x$ \\
\hline Y6 & 5 & 4 & 5 & 40 & $\times$ & O \\
\hline $\mathrm{Y} 7$ & 7 & 7 & 3 & 7 & $\times$ & $x$ \\
\hline Y8 & 5.5 & 5.5 & 5 & 50 & $\times$ & 0 \\
\hline Y の平均 & 6.88 & 5.88 & 8.1 & 23.1 & & \\
\hline 全ての平均 & 6.75 & 5.88 & 6.1 & 16.1 & & \\
\hline
\end{tabular}

表 14 作業に用いた映画夕イトル

\begin{tabular}{ll}
\hline ID & 映画のタイトル \\
\hline M1 & ALWAYS 三丁目の夕日 \\
M2 & チャーリーとチョコレート工場 \\
M3 & ヘイフラワーとキルトシュー \\
\hline
\end{tabular}

表 15 実験用レビューの詳細

\begin{tabular}{cccccc}
\hline \multirow{2}{*}{ ファイル ID } & \multirow{2}{*}{ 文数 } & \multirow{2}{*}{ 平均文字数 } & \multicolumn{2}{c}{ 文字数 } & \multirow{2}{*}{ 文字数（計） } \\
\cline { 4 - 5 } & & & 最小 & \\
\hline M1 & 19.5 & 620.8 & 996 & 195 & 6,208 \\
M2 & 16.8 & 504.7 & 949 & 162 & 5,047 \\
M3 & 15.9 & 514.5 & 942 & 249 & 5,145 \\
\hline 平均 & 17.4 & 546.7 & - & - & \\
\hline *文字数には記号とスペースを含む. & & &
\end{tabular}


表 16 フォーカスグループインタビューの主な質問

\begin{tabular}{ll}
\hline ID & 質問項目 \\
\hline Q1 & 下調べで参考となる情報は何か \\
Q2 & 参考になると下線付与した部分について \\
Q3 & 他人の書いたものを参考とするのに重要な要素は \\
\hline
\end{tabular}

品レビューずつ行い，次の作品レビューに進んだ後で前の作品レビューに戻ることはできない． 1 映画に関する 10 件の作品レビューについて作業が終わった時点で，その 10 件中で最も参考 となった作品レビューを選択し，その理由を回答してもらった。この作業を 3 つの映画に関し て行った。被験者間で下線付与した部分が重なり，かつ著者が同じ内容に下線が引かれている と判断した場合，同じ箇所に対する下線とした。以下に実例を示す.

\section{やっぱり期待外れでありましたよ。 …ア}

とてもほのぼのとした良い映画。 ‥

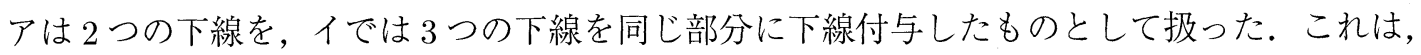
まったく同じ部分に下線が引かれていなくとも，構成要素として関連性がある部分を分離して 考え難かったためである.

\section{2 フォーカスグループインタビュー}

被験者の参考にする部分に対する考えを明らかにするために，作業終了後に休憩を挟んだ後， グループごとの被験者全員に対してフォーカスグループインタビューを行った.フォーカスグ ループインタビューでは, グループの 8 名全員にひとつの部屋に入ってもらい, 表 16 に示す 主な質問を軸にして，被験者全員に自由に発言を行ってもらった．被験者から新たな議論の種 がまかれた場合，その内容について我々が用意した質問と同じように議論してもらった。モデ レータは著者がつとめた．会場では机をコの字型に並べ，被験者間の発言の様子がわかるよう にした。

\section{7 被験者実験の結果と考察}

\section{1 事前アンケート}

表 13 より，グループXとグループ Y では趣味としてインターネットを使う時間が大きく違 う。また，グループXがネット上の情報を参考として映画を見るのに対し，グループYはあま り下調べもネット上の情報を参考にもしていない. 


\section{2 被験者による下線付与}

表 17 は，実験用レビューと下線が付与された部分の特徵である。実験用レビューへの感情表 現の夕グ付けは筆者が行った。表 17 は最も参考となる作品レビューを選んだ理由である．表 17, 表 18 中の R10, R17，R23，R28 は最も参考になるとされた作品レビューの IDである. 参 考とする部分の下線の数には, 特に参考となった部分の下線の数も含まれる.

\section{3 グループ間での下線付与の差異}

表 13 に示したように，被験者両グループの性質は異なる。しかし被験者により下線付与され た部分の性質に差はなかった，被験者にとって重要な部分は，「態度」や「理由」を含み映画の 感想を記述する部分と,「態度」や「理由」を含まず映画の内容や特徵を説明する部分に大別で き，それは被験者の性質に関わらなかった，表 $17 に$ 示すように，実験用レビュー全体で「態度」 と「理由」は高い確率で下線付与されており，これも被験者の性質に関わらず参考とすべき情 報として認識されていた。また，どちらのグループも最も参考になる作品レビューとして選ん だものは作品レビューR10, R17, R23 およびR28で共通していた.

\section{4 被験者間での下線付与の差異}

「態度」と「理由」には多く下線付与されており，被験者間でも下線付与の傾向に顕著な差は なかった。「態度」と「理由」以外の下線付与部分では，映画のストーリーの記述が多かった。 ただし，一部の被験者は下線を付与しなかった。これは後のフォーカスグループインタビュー で，僅かなストーリーの記述でもネタバレとして敬遠するためであることがわかった。

表 17 実験用レビューと下線付与された部分の特徴

\begin{tabular}{|c|c|c|c|c|c|c|c|c|}
\hline & \multirow{2}{*}{ 文字数 } & \multirow{2}{*}{ 下線数 ${ }^{* 2}$} & \multicolumn{2}{|c|}{ 「態度」 } & \multicolumn{2}{|c|}{ 「理由」 } & \multirow{2}{*}{$\begin{array}{l}\text { 「態度」「理 } \\
\text { 由」のない } \\
\text { 下線数 }\end{array}$} & \multirow{2}{*}{$\begin{array}{l}\text { 特に参考と } \\
\text { なる部分の } \\
\text { 下線のべ数 }\end{array}$} \\
\hline & & & 数 & 下線付与率 & 数 & 下線付与率 & & \\
\hline $\mathrm{M} 1^{* 1}$ & 620.8 & 12.2 & 10.8 & 81.5 & 4.2 & 81.0 & 4.4 & 9.6 \\
\hline R10 & 907 & 22 & 12 & 83.3 & 6 & 100.0 & 10 & 14 \\
\hline $\mathrm{M} 2^{* 1}$ & 504.7 & 14.9 & 11.2 & 94.6 & 4.8 & 85.4 & 4.9 & 8.6 \\
\hline $\mathrm{R} 17$ & 726 & 27 & 15 & 86.7 & 4 & 57.1 & 16 & 13 \\
\hline $\mathrm{M}^{* 1}$ & 514.5 & 11.7 & 11.7 & 83.8 & 5.6 & 73.2 & 3.2 & 8.6 \\
\hline $\mathrm{R} 23$ & 655 & 14 & 7 & 100.0 & 5 & 100.0 & 7 & 11 \\
\hline $\mathrm{R} 28$ & 942 & 18 & 28 & 75.0 & 10 & 62.5 & 3 & 11 \\
\hline 全レビュー*1 & 522.0 & 12.9 & 11.2 & 88.3 & 4.9 & 79.5 & 4.1 & 8.9 \\
\hline
\end{tabular}

*1 10 件のテキスト中での平均.

$*_{2}$ 参考になった下線が引かれた箇所の数. 
映画 $\mathrm{M} 2$ の作品レビューには「虫が苦手な人は見ないほうがいいかも」との記述があり, 複数 の被験者から特に参考となる下線がひかれた。また M3 の作品レビューでの「アメリ好きにお すすめ」といった記述も同様であった．特に参考となる部分については，キャラクター重視も あれば，ストーリー重視もあり，他にも被験者各々が気になる観点について下線が引かれるこ とがわかった。このことから被験者の趣味趣向や知識が強く反映され，被験者それぞれにとっ て異なる部分が選ばれるとわかった。

実験用レビューに出現した全ての感情表現の「態度」337 箇所中，86.6\%にあたる 292 箇所， 全ての「理由」 146 箇所中， $79.4 \%$ にあたる 116 箇所で下線付与された。「態度」と「理由」ど ちらも無い部分に付与された下線は全下線 338 箇所中の $32.2 \%$ にある 125 箇所で，映画を見 に来た人の様子による事実報告や映画のストーリー，特徵的な映画の場面を実体験から解説し ている部分への付与が多かった。特に参考となる下線が付与された部分の特徴を調べると，「態

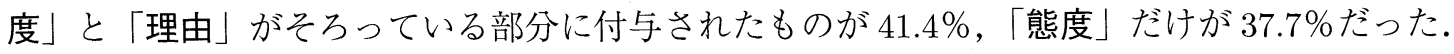

「態度」も「理由」も無い部分は $20.9 \%$ たっったとから，特に参考になる部分を選択するとき， 「態度」と「理由」が出現するかどうかも関連していると考えられた。

\section{5 最も参考となる作品レビュー}

表 17 に示すように，特に参考となる作品レビューとされた R10，R17，R23，R28の4件は どれも文字数, 下線数, 特に参考となった下線数ともに多かったが，それ以外の特徵について は一定の傾向が見られなかった。これら特に参考となる作品レビューには，選んだ理由を示し た表 18 からもわかるように, 被験者個々の趣味や嗜好に合致する点がわかりやすく記述されて いたと考えられる。被験者によって最も参考となる作品レビューの内容や観点は異なっている ことから，参考となる作品レビューではただ単に「この映画は面白かった」ということだけで なく，映画の中のどのような部分がどのように面白かったのかの記述が必要とされた．これは 我々の主張する「理由」の部分に該当している.

\section{6 フォーカスグループインタビュー}

フォーカスグループインタビューでは, 表 16 の質問を中心に議論してもらった. その結果, 被験者が参考になる情報を選ぶ基準として主に以下の 8 点があげられた.

(1) 映画の上映場所, 日時, 長さがわかる

(2) 出演者がわかる

(3)あらすじ，見所がわかる

(4) 映画がどんな人に向けられているか

(5) 映画をみてどう思ったか

(6) 作品レビューの書き手の人物像がうかがえる部分 
表 18 最も参考になった作品レビューとその理由

\begin{tabular}{|c|c|c|}
\hline ID & $\begin{array}{l}\text { 最も参考に } \\
\text { なつ作品 } \\
\text { レビュー }\end{array}$ & 参考になった理由の要点 \\
\hline $\mathrm{X} 2$ & \multirow{7}{*}{ R10 } & $\begin{array}{l}\text { 内容がわかりやすかった．原作を絡めていてよかった．他のものに比べ感情的でな } \\
\text { かった. }\end{array}$ \\
\hline $\mathrm{X} 3$ & & 対象と思われる年代が書いてあったので. \\
\hline $\mathrm{X} 6$ & & 感動したことが伝わってきたので.オヤジ世代が感動する点が気になったので. \\
\hline Y1 & & 映画の概略が感想の前に書かれていて参考になった。簡潔でよかった。 \\
\hline Y3 & & $\begin{array}{l}\text { 時代背景がわかったことで，映画の雱囲気がわかった。映画のイメージがふくらん } \\
\text { だ. }\end{array}$ \\
\hline Y6 & & $\begin{array}{l}\text { 原作, 舞台とその背景, ストーリー, 俳優の演技の出来, 映画の特徵が説明されて } \\
\text { いた. }\end{array}$ \\
\hline Y7 & & 映画の概要, 主役とその演技, 感想やコメント, 特に客観的な意見が信頼に足りた。 \\
\hline Y4 & \multirow{6}{*}{$\mathrm{R} 17$} & $\begin{array}{l}\text { 予備知識として知っておきたいことが押さえられている. 感想が押し付けがましく } \\
\text { ない. }\end{array}$ \\
\hline Y6 & & $\begin{array}{l}\text { 自分のイメージと違う意見がよかった．短い文だが簡潔にまとめられたムダのない } \\
\text { 意見だった. }\end{array}$ \\
\hline Y7 & & $\begin{array}{l}\text { ストーリーの紹介と映画の感想が書かれているなど, トータルでよかった. 主演や } \\
\text { 監督もわかる. }\end{array}$ \\
\hline $\mathrm{X} 1$ & & $\begin{array}{l}\text { 映画にまつわる周辺の情報について広く書かれていてよい. 感想については物足り } \\
\text { なさも. }\end{array}$ \\
\hline $\mathrm{X} 3$ & & $\begin{array}{l}\text { ストーリーが書いてあったので. 自分も好きなジョニーディップが好きと書いてあ } \\
\text { ク，共感した. }\end{array}$ \\
\hline $\mathrm{X} 6$ & & $\begin{array}{l}\text { 映画の舞台をわかりやすく説明している.他のものより理解しやすいレビューだっ } \\
\text { た. }\end{array}$ \\
\hline $\mathrm{X} 2$ & \multirow{5}{*}{$\mathrm{R} 23$} & $\begin{array}{l}\text { 映画に興味を持てるような映画評だったから。また、キャラクターの説明もよかっ } \\
\text { た。 }\end{array}$ \\
\hline $\mathrm{X} 3$ & & $\begin{array}{l}\text { 他の映画評が見た目ばかりに言及していたのに対し、ストーリーにも言及していた } \\
\text { から。 }\end{array}$ \\
\hline Y5 & & 出演人物の紹介とストーリーについての言及が一番よかったから。 \\
\hline Y6 & & ストーリーと登場人物、映画の特徵がわかりやすかった。 \\
\hline $\mathrm{Y} 7$ & & 他に参考になるレビューがなかったから。 \\
\hline $\mathrm{X} 1$ & \multirow{5}{*}{$\mathrm{R} 28$} & $\begin{array}{l}\text { 「アメリが好きな人」「インテリアが好きな人」にオススメと書いてあってわかりや } \\
\text { すかったから。 }\end{array}$ \\
\hline $\mathrm{X} 5$ & & 「アアメリが好きな人」「インテリアが好きな人」にオススメと書いてあったので。 \\
\hline $\mathrm{X} 6$ & & $\begin{array}{l}\text { 単館系であると言及されていて参考になった。どんな場面をみて書いたか確かめた } \\
\text { くなった。 }\end{array}$ \\
\hline Y1 & & $\begin{array}{l}\text { インテリアや登場人物の話だけではなく、「アメリ好きに」や「単館系」などと説明 } \\
\text { されていた。 }\end{array}$ \\
\hline Y3 & & 「アメリ好きにオススメ」なども含め、イメージしやすい情報が多く書かれていた。 \\
\hline
\end{tabular}


(7) 決め付けではなく，筋道立った記述により共感できる/できないの判断ができる部分

(8)〜のような映画など，比較対象がわかる

これらの点は，このような部分に下線付与しなかった被験者からも支持された．(1)～(3)につ いては，作品レビューでなくとも得られる事実報告のような内容の記述である。これに対して (4)〜8は，作品レビューでなければ得られない，主観的な内容の記述である.

フォーカスグループインタビューの内容から，我々は以下のような仮説を立てた．友人や知 人からのクチコミのほうが，ネットに書き込まれた情報よりも信頼できるという意見が多かっ たことから，被験者にとって最も参考としやすい情報は「書き手がどんな趣向でどのような性 質を持つ人かわかっていること」である，その中でも，なぜ書き手がそういった考えを記述し たか理解するため，書き手の考えを理解する手がかりになる具体的な「理由」の記述があるか どうかは，書き手の性質がわからないときに，大きな判断材料となる。ブログなどに書かれた 作品レビューに理由のない態度のみが記述されている場合, その作品レビューは理由があるも のに比べて参考にし難く，利用者がその内容を参考にできるかどうかを判断することができな い。それに対して，明確な比較対象や具体的な説明，さらには筋道立てた内容があれば，利用 者はそれに共感できるかどうかを判断することができる，共感できれば作品への興味が増幅さ れ，共感できなければ作品への興味が薄れる。こういった判断ができる作品レビューには理解 や信頼が生じ，参考になる情報となる。

\section{7 「理由」の分析のまとめ}

実験と分析の結果から，作品レビューの利用者は「理由」を手がかりとして，書き手の嗜好や 性質および作品の性質が強く影響する作品レビューのテキスト内容が自分にとって信頼できる のか，参考にできるのかを判断していると考えられた．態度」と「理由」の組み合わせは，作 品レビューのような作品レビューにおいて，とても重要な要素である．本稿にて行われた実験 においては，被験者が作品レビューを見て映画を見るかどうか決める際には，まず「理由」や 「態度」，および事実報告の記述の有無によってその作品レビューが参考になるかどうかを，さ らに「理由」や「態度」の内容に共感できるかどうかにより，その映画についての最終的な判 断が下されていた。

\section{8 おわりに}

本稿では, まずWeb 上の作品レビュー 82 件に対し構成要素を人手で夕グ付けることで, 感 情表現のモデルについて検討し，「態度」「主体」「対象」「理由」の上位要素からなる4つ組み のモデルを提案した。「主体」「対象」については省略されるものとされないパ夕ンが，「理由」 については明確なものと暗黙的なもの, さらに主観的なものと事実にもとづくものに着目した. 
次に作品レビューにおける「理由」の重要性に注目し，その特徴と働きを調べるため，別のテ キストによる追加分析とフォーカスグループインタビューを行った。その結果，書籍や映画な どを対象とした書き手の嗜好や状況がその感想に強く反映される作品レビューのようなテキス トでは，書き手の態度だけでなく，感情表現の構成要素が重要とわかった．特に理由が嗜好や 性質のわからない第三者が書いたテキストを利用者が理解し，鑑賞する作品を選択するのに参 考にする上で重要だとわかった。また，あらすじのような情報も作品レビューにおいて鑑賞す る作品を選択するのに参考になる情報とわかった。

今後は，本稿にて定義した各要素の構造を分析し，自動抽出する手法について検討する．ま たフォーカスグループインタビューにおける質的な分析を行った点について，量的な調査から 客観的な分析も必要である。今回はWeb上のテキストを中心に分析を行ったが，テキスト媒体 や購読対象の違いによる特性についても分析を行う予定である。今回の調査によってあらすじ などの記述も作品レビューにおいて重要であるとわかったが，その扱いについても今後議論す る必要がある。

\section{謝 辞}

本研究を進めるにあたり，多くの有益なコメントを下さった豊橋技術科学大学情報工学系の 関洋平助手，および本論文の査読者の方に深く感謝します。

\section{参考文献}

AAAI (2006). "Spring Symposium on Computational Approaches to Analyzing Weblogs." Stanford, CA, USA.

ACL (2006). "Sentiment and Subjectivity in Text." Workshop at the Annual Meeting of the Association of Computational Linguistics, Sydney.

Cohen, J. (1960). "A Coefficient of Agreement for Nominal Scales." Educational and Psychological Measurement, 20, pp. 37-46.

EAAT (2004). "Proceedings of AAAI Spring Symposium on Exploring Attitude and Affect in Text: Theories and Applications." Stanford, Technical Report SS-04-07.

EACL (2006). "Proceedings of the Workshop on NEW TEXT-Wikis and blogs and other dynamic text sources." Trento, Italy.

言語処理学会 (2005). 第 11 回年次大会発表論文集 テーマセッション感情・感性の言語学.

言語処理学会 (2006). 第 12 回年次大会ワークショップ「感情・評価・態度と言語」論文集.

Glaser, B. G. and Strauss, A. L. (1967). "The Discovery of Grounded Theory." Chicago, Aldine. 
Shanahan, J.G., Qu, Y. and Wiebe, J. (2005). "Computing Attitude and Affect in Text: Theory and Applications (The Information Retrieval Series)." Springer.

Wiebe, J., Wilson, T. and Cardie, C. (2005). "Annotating expressions of opinions and emotions in language." Language Resources and Evaluation, 39, (2-3), pp. 165-210.

木戸光子 著, 佐久間まゆみ 編 (1989). “文章構造と要約文の諸相 第 7 章文の機能による要約文 の特徴.”くろしお出版, pp. 112-125.

Kim, S.M. and Hovy, E. (2004). "Determing the sentiment of opinions." Proceeding of Conference on Computational Lin-guistics (CoNLL-2004), pp. 1367-1373.

Keith, F.P. 著, 川合隆男 監訳 (2005). “社会的調査入門量的調査と質的調査の活用.”慶應義塾 大学出版会.

小林のぞみ, 乾健太郎, 松本裕治, 立石健二, 福島俊一 (2005). “意見抽出のための評価表現の収 集, 自然言語処理.” 12(2), pp. 203-222.

Liu, H., Lieberman and H., Selker, T. (2003). "A Model of Textual Affect Sensing using RealWorld Knowledge." Proceedings of IUI 2003.

Landis, J.R. and Koch, G.G. (1977). "The measurement of observer agreement for categorical data." Biometrics, 33, pp. 159-174.

森田良行, 松木正恵 (1989). “日本語表現文型：用例中心・複合辞の意味と用法.”アルク. 中村明 編 (1993). “感情表現辞典.”東京堂出版.

中山記男, 江口浩二, 神門典子 (2005). “感情表現のモデル.” 言語処理学会第 11 回年次大会発表 論文, pp. 149-152.

那須川哲哉, 金山博 (2004). “文脈一貫性を利用した極性付評価表現の語彙獲得.” 情報処理学会 研究報告 “自然言語処理 (NL162-16).” pp. 109-116.

大塚裕子 (2004). “自由記述アンケート回答の意図抽出および自動分類に関する研究.” 神戸大 学大学院自然科学研究科博士論文.

杉田茂樹, 江口浩二 (2001). “目録データベースと Web コンテンツの統合的利用方式.” 情報処 理学会研究報告 情報学基礎 (NL142-), pp. 153-158.

田中努, 徳久雅人, 村上仁一, 池原悟 (2004). “結合価パターンへの情緒生起情報の付与.” 言語処 理学会第 10 回年次大会発表論文, pp. 345-348.

Turney, P. D. (2002). "Thumbs up? thumbs down? Semantic Orientation Applied to Unsupervised Classification of Reviews." In Proceedings of the 40th Annual Meeting of the Association for Computational Linguistics (ACL-2002), pp. 417-424.

立石健二, 石黒義英, 福島俊一 (2004). “インターネットからの評判情報検索.”人工知能学会誌, 19(3), pp. 317-323.

舘野昌一 (2002) “「お客様の声」に含まれるテキスト感性表現の抽出方法.” 情報処理学会研究 
報告 自然言語処理 (NL153-14), pp. 105-112.

\section{略歴}

中山 記男：2001 年芝浦工業大学工学部工業経営学科卒業. 2003 年芝浦工業大 学大学院工学研究科電気工学専攻修士課程修了. 同年, 総合研究大学院大学 情報学専攻博士課程に入学, 現在に至る. 自然言語処理の研究に従事.

神門 典子：1994 年慶應義塾大学文学研究科博士課程修了. 博士（図書館・情報 学)．1995 年米国シラキウス大学情報学部客員研究員, 1996〜1997 年デンマー ク王立図書館情報大学客員研究員. 1998 年学術情報センター助教授. 2000 年 国立情報学研究所助教授, 2002 年より総合研究大学院大学助教授を併任, 2004 年より国立情報学研究所教授並びに総合研究大学院大学教授, 現在に至る. テキスト構造を用いた検索と情報活用支援, 言語横断検索, 情報検索システ ムの評価等の研究に従事. ACM-SIGIR, ASIS\&T, 言語処理学会, 日本図書 館情報学会各会員.

(2006 年 4 月 20 日 受付)

(2006 年 8 月 7 日 再受付)

(2006 年 10 月 28 日 再々受付)

(2006 年 11 月 22 日 採録) 